\title{
'Kings among their subjects'? Ernst Thälmann, Harry Pollitt and the leadership cult as Stalinization
}

DOI:

10.1057/9780230227583_7

\section{Document Version}

Accepted author manuscript

Link to publication record in Manchester Research Explorer

\section{Citation for published version (APA):}

LaPorte, N. (Ed.), \& Morgan, K. (2008). 'Kings among their subjects'? Ernst Thälmann, Harry Pollitt and the leadership cult as Stalinization. In N. LaPorte, K. Morgan, \& M. Worley (Eds.), Bolshevism, Stalinism and the Comintern: Perspectives on Stalinization, 1917-53 (pp. 124-145). Palgrave Macmillan Ltd.

https://doi.org/10.1057/9780230227583_7

Published in:

Bolshevism, Stalinism and the Comintern

\section{Citing this paper}

Please note that where the full-text provided on Manchester Research Explorer is the Author Accepted Manuscript or Proof version this may differ from the final Published version. If citing, it is advised that you check and use the publisher's definitive version.

\section{General rights}

Copyright and moral rights for the publications made accessible in the Research Explorer are retained by the authors and/or other copyright owners and it is a condition of accessing publications that users recognise and abide by the legal requirements associated with these rights.

\section{Takedown policy}

If you believe that this document breaches copyright please refer to the University of Manchester's Takedown Procedures [http://man.ac.uk/04Y6Bo] or contact uml.scholarlycommunications@manchester.ac.uk providing relevant details, so we can investigate your claim.

\section{OPEN ACCESS}


'Kings among their subjects'? Ernst Thälmann, Harry Pollitt and the leadership cult as stalinization

\section{Norman LaPorte and Kevin Morgan}

\section{Stalinization and the 'cult of personality'}

The cogency and distinctiveness of Weber's original concept of stalinization lay in its precision. At a general level, several defining features of the stalinized communist parties could already be regarded as axiomatic. Disciplined and centralized, according to the precepts of democratic centralism, through the projection of these characteristics internationally these parties always accepted the ultimate authority of the Comintern and explicitly prioritized the interests of the USSR. Few now question that there is more to the history of communism than this. Nevertheless, as a description of its organizational modus operandi these issues are no more the subject of serious contention than the dates - ever sparser - of Comintern congresses or the location of its headquarters in Moscow. The problem with much historical literature on communist parties, even in quite sophisticated variants, is how much if it fails to gets beyond such description and its thickening into narrative. Stalinism, conceived as this relationship of centralization and subordination, continues to be seen as providing both description and explanation - which means, in the last analysis, that nothing is explained. Easy exposition leads to easy refutation, and debates within the literature not infrequently have a ritualistic character. The strength of Weber's stalinization thesis, on the other hand, lay in a genuine sense of process, a rigorous sense of periodization and the careful delineation of both determining and contingent factors. It is precisely this attention to the timing and weighting of different explanatory variables that lends itself to meaningful comparison. Weber's work has sometimes been criticized for the limited character of what it sought to explain. However, in accounting for the political subordination of the communist parties to Moscow - and this after all is no peripheral issue - his Wandlung des deutschen Kommunismus remains a key point of reference.

A conspicuous manifestation of the stalinization process was the emergence of a single dominant leading figure: usually, after Stalin's example, the general secretary. ${ }^{1}$ From Borkenau's commentaries of the 1930s, through Khrushchev's secret speech in 1956, the cult 
of these individuals provided both an epitome of centralization and a feature apparently distinguishing the Stalinist party from 'Leninism' or 'Bolshevism'. 2 Throughout the Comintern, Stalin's ascendancy in 1929-30 was confirmed by the sweeping aside of established party leaders and the installation of a new leadership cohort. Indistinctly at first, there emerged at the head of their parties figures like Maurice Thorez in France, Klement Gottwald in Czechoslovakia and Earl Browder in the USA. The German Ernst Thälmann and the Briton Harry Pollitt - subjects of the present study - can also be grouped with this 'Stalin generation' of CPleaders, though Thälmann has the additional interest of providing a prototype and exemplar for the others. Except through death or imprisonment, these figures remained in position throughout the Comintern period, and in most cases until after Stalin's death. Where previously the leadership of Comintern sections had to varying degrees been characterized by factionalism and discontinuity, the closed character of democratic centralism now encouraged the perpetuation of leaders at once enjoying Stalin's favour and holding whatever levers of patronage and power existed at a national level. Privately, the centralization of communications, including encrypted wireless messages, accentuated central authority through the control of information. Publicly, communist parties competed with other political formations in exploiting the charismatic or symbolic attributes of personal authority. As Marc Lazar observes, these ritualized cults can call to mind Hannah Arendt's notion of the totalitarian leader, magically defending the movement against the world beyond. ${ }^{3}$

Even so, the whole business was fraught with ambiguity. Stalinization itself was a dynamic process that in its first stages undermined intermediate leadership through antibureaucratic rhetoric and the exposure of such leaders' dispensability. Though superficially both party and Comintern apparatus resembled a Michelsian oligarchy, their material and ideological dependency on the Soviet party, strongly emphasized by Weber, subjected them to systematic forms of upward accountability. If there was to be a cult of leadership, Stalin's ideal of a monolithic single will implied that this too should be centred on Moscow, and on the person of Stalin himself. In reality, the issue was more complex. ${ }^{4}$ On the one hand, the hierarchical organization of communist parties set a premium on leadership qualities at every level, not just at the centre, and the assumption of a 'leading role' towards the world beyond encouraged similar postures even on the part of rank-and file party activists. At the same time, the stabilization of leadership, at every level, provided a possible resource in the negotiation of 
relations between individual and party and between party and international. This meant that personalized leadership provided both asset and threat: hence the rationale for the formation of a controlled and Bolshevized leadership cohort, both through the Moscow-based training of the Lenin School, with its dislocation from independent sources of political capital, and through the painstaking construction of biographical filters and control mechanisms.

Moscow's dilemma was that stalinized leadership structures required the assertion of authority domestically without diluting the concentration of authority in Moscow itself. The tensions that resulted were not always realized or explicitly articulated as such. Instead, they might be likened to the phenomenon of 'little Stalins' threatening the reach of central government within the USSR itself. ${ }^{5}$ With the export of these practices to the post-war People's Democracies, it was noticeably the 'strong cults' around Tito, Enver Hoxha and Ceaşescu which became most associated with instincts of independence. ${ }^{6}$ Sarah Davies has even suggested that Stalin's ambivalence regarding cultic behaviour was not merely its further manifestation in the guise of modesty, but a sign of his appreciation of its 'double-edged' character. ${ }^{7}$ Already by 1929 Thälmann was being stylized as the 'German Stalin'. ${ }^{8}$ It was equally the logic of Stalinization, however, that there could and should be only one Stalin.

\section{Transnational and diachronic comparators}

Thälmann and Pollitt make suitable but complex comparators. Born in 1886 and 1890 respectively, they were representatives of a generation of working-class activists drawn to socialism in the first years of the century and to communism in the aftermath of war and the Russian revolution. Joining their communist parties from positions of relative obscurity in 1920-1, each then experienced rapid political advancement and by 1924 had risen to political bureau level. At this point, however, their careers diverged significantly. Already appointed KPD vice-chairman in January 1924, Thälmann survived the subsequent ousting of the leftist Fischer-Maslow leadership and in September 1925 emerged as party chairman as head of the so-called pro-Soviet left. Pollitt, by contrast, was thwarted in a factional bid for the CPGB leadership in 1923. From mid-1924 he functioned instead as general secretary of the National 
Minority Movement (NMM), the reconstituted British section of the Profintern; and it was not until August 1929 that he attained the leadership of the party itself.

In one sense, the difference in chronology is deceptive. When Pollitt at last became CPGB general secretary, he could have been under no doubt that the opening arose through changing political circumstances in Moscow, ${ }^{9}$ and in the spring of 1929 had been tested with a Comintern mission to the recalcitrant American party. On the other hand, Thälmann, despite his apparent seniority, had had his dependence on the same source of authority publicly demonstrated just the previous year, when Stalin had him reinstated as KPD leader against the overwhelming verdict of the party's central committee. The occasion for the incident was an embezzlement scandal involving Thälmann's right-hand man, John Wittorf. Nevertheless, in this case too the indispensable prerequisite for Moscow's preferment was Thälmann's commitment to the 'new' Class Against Class line. It is in this sense that such figures can be grouped together as agents of stalinization. 'Now I have the German party in my hand!', Stalin reportedly boasted after the Wittorf affair. The function of leadership figure as transmission belt seems conclusively attested. ${ }^{10}$

At the same time, differences even of a few years could count for a good deal in the helter-skelter world of the Comintern. Already well established in the 1920s, Thälmann's Führerkult, predates by several years the international phenomenon of mimetic cults, usually dated from the mid-1930s. ${ }^{11}$ The full development of Stalin's own cult is usually traced only from the commemoration of his fiftieth birthday in 1929; fuller articulations like Henri Barbusse's best-selling hagiography appeared only in $1935 .{ }^{12}$ While the synchronicity of political lines like Class Against Class may be unaffected, other cultural or organizational features of the Stalinized party evidently developed a good deal more unevenly. In the precocious development of the Thälmann cult, the KPD may even have provided a sort of model of the Stalinized party that might then be taken up by other parties like the CPGB, to which by the late 1920s the German party extended systematic mentorship and oversight. ${ }^{13}$

Nevertheless, the promotion of a Thälmann-style cult in Britain dates only from after the KPD's suppression by the Nazis and the imprisonment of Thälmann himself. This not only meant adapting the cult to a very different social and political environment. It meant doing so as the instrument of a popular-front style of politics, in a period in which the centralized communications of the Stalinization model became significantly atrophied through terror and 
neglect. The comparison between Thälmann and Pollitt is thus both a diachronic one, between the Third Period and the popular front, and a transnational one. Indeed, the two aspects are indistinguishable. Because the contrasting fortunes of their two parties were so closely bound up with distinct phases of Comintern history, any satisfactory comparison between them has to take account of these variations over time.

Within the present constraints of space, only one or two aspects of the question can be examined here. First we look at class, and more specifically the common working-class credentials required of the ideal-type stalinist leader. Then we look at faction, whether as a rationale for such forms of leadership or as a constraint upon them. Crudely summarized, our comparison shows that Pollitt's leadership more than Thälmann's was anchored in a class identity rather than faction, and that this was of some political significance. In the laxer environment of the popular front, it made for a greater independence of judgement than the stalinization model has traditionally accommodated. But at the same time, almost by definition, this was not expressed in the factional terms of an alternative political platform.

\section{Authenticities of class}

Bolshevization was from the start expounded in primarily political terms of overcoming factionalism and heterodoxy through the acceptance of binding party discipline. At the same time, political qualities were explicitly linked to a process of proletarianization, from the workplace basis of party organization, to the class-struggle credentials required of responsible party leaders. What class signified was seemingly unambiguous. The Bolsheviks, like other socialists, had long used class in a normative sense to conveyed distinctive moral and political attributes. Bolshevization now meant the narrowing down of these qualities to the 'party' attributes of firmness, loyalty and discipline. Individualism, vacillation, opportunism and adventurism, on the other hand, were all damned as representing an alien class outlook. Already in 1920, in the provision made for purges in the Comintern's original conditions of admission, their target was defined in precisely such terms: of 'petty-bourgeois elements' worming their way into the workers' party. ${ }^{14}$ Such phrases may have been used indiscriminately, but this did not mean that they lacked any practical application. Both party 
cohesion and its wider projection were seen as requiring strong, authentic proletarian leadership figures.

Thälmann and Pollitt both fitted the bill. Like many communist parties, the KPD was initially dominated by intellectuals like Paul Levi, whose defiant stance in 1921 seemed to confirm the unreliability of such figures. ${ }^{15}$ The Fischer-Maslow group, with whom Thälmann first entered the party leadership, was hardly more dependable, and it was therefore as the embodiment of the KPD's 'healthy, proletarian elements' that Thälmann emerged as party chairman. ${ }^{16}$ A dockworker, veteran of the pre-war socialist movement, and 'hero' of the socalled 'Hamburg Rising' of 1923, Thälmann in Zinoviev's words was 'the gold of the [German] working class' ${ }^{17}$ Unlike the younger Lenin School generation, whose class credentials were carefully vetted before admission to the school, he was also one of the more experienced figures whose advancement Stalin described as vital for Bolshevization and in the contest with social democracy. ${ }^{18}$ Proletarian in manner, speech and dress, his party loyalty was conflated with an almost existential sense of class to produce a visceral identification with Stalinism that nothing would ultimately sway. Thälmann never showed any interest in a personal platform or in the theoretical or programmatic distinctions on which one might have been based. Thorez, Gottwald, Browder - at least for the time being - were all of the same type; and so too in Britain was the boilermaker Pollitt.

To some degree, this represented a process of homogenization. Nevertheless, the rudimentary communist categories of class, sometimes borrowed by the movement's historians, concealed numerous distinctions of potentially formative significance, here including those of generation, political culture and work experience. Stalin himself stressed that the proletariat was 'not a sharply circumscribed class', but lay exposed on one side to proletarianized petty bourgeois elements, and on the other to the bribery and corruption of its upper strata by capitalism. Again, Stalin identified these alien elements with political problems such as factionalism, disorganization and the disruption of the party from within. ${ }^{19}$ The Comintern's preoccupation with class purity was less intense than within the USSR itself. ${ }^{20}$ Exceptionally, a figure like the Italian Togliatti could survive even at the head of his party. Nevertheless, student reports from the Lenin School reveal a similar concern to root out the ideological residues of the stigmatized 'labour aristocracy' or 'petty bourgeois'. ${ }^{21}$ The standard signifier 'working class' on party questionnaires thus concealed complexities that 
could make for distinct approaches to leadership, involving resources and liabilities that would have been easier to manage had they been more easily extricable from each other.

Thälmann, more perhaps than Pollitt, had liabilities to conceal. According to the cult constructed around him after 1924, he had grown up in a model proletarian household. Central to the narrative was his father, an innkeeper and small trader styled 'Comrade Jan', who as an SPD member had bravely convened illegal party meetings at the time of the Bismarckian antisocialist laws. ${ }^{22}$ Already the conventions of a sort of 'master narrative' of the communist leader's life were being established. ${ }^{23}$ Thälmann, however, had a very different story to tell when he came to produce a private autobiographical sketch during his imprisonment by the Nazis. Here his family life and schooling were described as 'in no way socialist', but if anything the reverse; while his father was a member, not of the SPD, but of 'all sorts of bourgeois and military associations' ${ }^{24}$ Thälmann's adhesion to the socialist movement was thus described in the same manuscript as a moment of epiphany: emerging from a socialist rally with literature clutched in his hand and anthems still ringing in his head, he sensed a 'new, vehement life' beginning. ${ }^{25}$ Conversion narratives like this have figured prominently in communist autobiographies. ${ }^{26}$ However, in the public lives of party leaders, whose deep proletarian roots had to convey the authenticity of the party itself, they were possibly less common and less serviceable. ${ }^{27}$

Thälmann's mother was scarcely acknowledged at all. This too was characteristic. If class was a common denominator, it was in a distinctly gendered construction in which both Thälmann and Pollitt embodied the tough, masculine, fighting qualities of the heavy industrial worker. Communist autobiographies like those of Thorez and the American W.Z. Foster hence depicted only shadowy female figures and projected a proletarian pedigree through the masculine virtues of a father-figure. ${ }^{28}$ This was consistent with the depreciation of domestic ties implicit in the communist ambition of relentless, preferably factory-based activism. It was also consistent with Thälmann's persona as communist Führer and 'strongman'; and doubtless the authoritarian family structures of the Kaiserreich period can be traced in the pushing aside of mother and sister in favour a combative, masculine conception of his class. ${ }^{29}$ Thälmann's emergence as head of the paramilitary Roter Frontkämpferbund (RFB) reinforced these associations with the immediacy of mass spectacle, as during its massive set-piece 
demonstrations of the 1920s he took the clenched-fist salute of thousands of uniformed militants marching in military formation. ${ }^{30}$

In his autobiography, published in 1940, Pollitt confessed to never having liked salutes and slogans, and more specifically not the clenched-fist salute and Red Front slogan that originated with Thälmann's KPD. ${ }^{31}$ The significance of such details should not be overlooked. Growing up in a Lancashire textile district, Pollitt was a genuine cradle socialist who from an early stage deployed his early induction into the labour movement as a core component of his political persona. More distinctively, the primary political influence he acknowledged was that of his mother. Integrated into the world of paid employment, women in the textile districts were more than usually active both socially and politically; and from the buxom factory women who daubed his sexual organs with oil and cotton waste, to its opening portrait of his mother as model and counsellor, Pollitt's autobiography presented a curiously feminized presentation of his class credentials. Even his father, a blacksmith's striker, embodied a relaxed and hedonistic sense of masculine camaraderie centred on the pub. Class could thus also be constructed in more inclusive terms, politicized as an instinct for 'unity', and potentially softening the friend-foe dichotomy so characteristic of German communism. ${ }^{32}$ Certainly, Pollitt in his autobiography betrayed a surprisingly attenuated sense of anathema, whether in respect of class or political enemies. ${ }^{33}$ On its very first page, he invoked the local policeman's wife as a source of support to his family, thus transmuting into an image of working-class community what by stalinist convention was a compromising and even dangerous connection.

Contrasting work experiences underlined the multivalency of class. Leaving school in 1900, Thälmann worked for two years in the family business as a drayman, repeatedly feuding with his father over remuneration. He then took up casual work in the Hamburg docks and over the next two decades was employed variously as a warehouseman, longshoreman, deckhand, furniture remover and brewery driver. Like Thorez's, this was an unskilled, unstable and precarious existence; and like Thorez's it was transmuted retrospectively into a more settled occupational identity, in Thälmann's case as dockworker. ${ }^{34}$ Significantly, Thälmann's adhesion to the SPD, in May 1903, predated by almost a year his enrolment in the appropriate trade union. ${ }^{35}$ Thälmann later attributed this to a theoretical bent and streak of idealism prevailing over the materialist motivations of the trade unionist. He also claimed to 
have spurned employment as a union official out of commitment to the interests of rank-andfile workers. ${ }^{36}$

The critique of bureaucracy was common to militants of this generation, and Pollitt also gave it forthright expression. However, where Thälmann, according to Ruth Fischer, represented a 'substratum of ... unskilled or semi-skilled workers' at a disadvantage with party politicians, Pollitt's rhetoric of independence was rooted in the values of the skilled worker. ${ }^{37}$ As a time-served boilermaker he belonged to one of Britain's oldest and most exclusive crafts, the epitome of the labour aristocracy so misprized in communist circles. Pollitt himself, in the Class Against Class period, was to come under fire for his 'legalistic' approach to union affairs; but his whole political charisma was bound up with this sense of identity. Where Thälmann at rallies would rip off his collar and tie in symbolic symbiosis with the outcasts of society, Pollitt dressed and comported himself like the time-served craftsman that he was, and insisted on the respectable credentials of a clean collar and tie. ${ }^{38}$ To a critic like George Hardy, a warm admirer of the KPD, Pollitt's dismissal of appeals to 'street-corner loungers' was only the most overt expression of this pervasive influence of the labour aristocracy within British communism. ${ }^{39}$

With what at first sight was the shared generational landmark of the First World War, different work experiences once more gave rise to very different experiences. Thälmann, being liable for the call-up, steadfastly carried out what he saw as his duty as an artilleryman on the Western Front, where he was wounded four times and 'received the Iron Cross, the insignia of wounded soldiers and the Hanseatic Cross'. In the autobiographical manuscript he produced during his imprisonment, he proudly noted that he was never long in garrison 'because I was not a malingerer, a scaredy cat (Angsthase) and coward'. ${ }^{40}$ Such attitudes could have no part in the public Thälmann myth, in which nothing was said to indicate that Thälmann had not always made his stand against chauvinism and social patriotism. Nevertheless, Thälmann's frontline experiences may help explain his matchless rapport with the RFB, whose relish for real and symbolic confrontation had its roots in the same wartime mentality.

Radicalized only in defeat, Thälmann was therefore not among those taking the 'direct path' to communism through the Spartacist League. ${ }^{41}$ Although he was in Hamburg during the November Revolution, he took no part in the workers' and soldiers' council movement. Instead, he joined the locally dominant Independent Social Democratic Party (USPD), which 
on its foundation in April 1917 was conceived as a return to the values of pre-war social democracy. It was only as the USPD increasingly split over the issue of revolution that Thälmann attached himself to its powerful left-wing faction and began to make his mark on the Hamburg city parliament and as chairman of his local party group. As a delegate to the USPD's Halle congress of October 1920, he was consequently among those who took the 'second', indirect route to communism through fusion with the Spartacists. In the summer of 1921, Thälmann made his first visit to Moscow as a delegate to the Comintern's third world congress, representing what was now the first mass communist party outside of Russia.

Pollitt, who was one of the British congress delegates, had also arrived at communism somewhat obliquely, though without Thälmann's hesitations. An opponent of the war from the outset, he was exempt from conscription as a skilled metalworker and fought instead a shop stewards' war against de-skilling and the militarization of labour. This was typical of the profoundly civilian formation of most of the CPGB's founding cohort, whose defining collective memory of the 'war in the workshops' was immortalized in books like Serving My Time and William Gallacher's Revolt on the Clyde (1936). It was thus as industrial militant that Pollitt was drawn into communist politics, initially through Sylvia Pankhurst's Workers' Socialist Federation (WSF). Centred in East London, where Pollitt now worked in the shipyards, the WSF had its origins in the women's suffrage movement and again provided Pollitt with the distinctive experience of speaking from otherwise all-women platforms for a body that some dismissed as a women's party. Detached from the 'unity negotiations' from which the CPGB emerged in mid-1920, Pollitt was to describe in his autobiography how for some time he continued to be regarded 'more as a militant trade unionist than as a Communist' ${ }^{4}{ }^{4}$

Though Thälmann was the elder of the two, and like Pollitt a longstanding socialist, any notion of generation as mere classification by birth date is here confounded. Thälmann's value to the Comintern was that he combined the quality of 'experience' which Stalin valued with an experience of Bolshevism that was hardly less formative than that of the Leninist generation proper. Pollitt's adhesion to communism, on the other hand, represented a less clear-cut break, and there was considerable continuity between his activities before and after becoming a communist. Though biography in theory was at the heart of the leadership cult, a life history like Pollitt's provided a source of personal capital that predated Stalinization and 
was irreducible to its central tenets. It is little wonder that the production of such narratives was viewed so warily, even in Stalin's own case, or that a party like the PCF failed to produce any such account apart from Thorez's ghost-written exercise in 'anti-individualism', Fils $d u$ peuple. $^{43}$

\section{Factionalism and dictatorship}

Factionalism was a major theme in Weber's account of Stalinization. Distinct political groupings with competing programmes played a critical role within the KPD, as previously within the SPD, and faction was the obvious basis of advancement within the German party. Thälmann's own rise to prominence came through his association with the revolutionary 'Left Opposition' centred on his local party organization in Wasserkante (Hamburg) and on the Fischer-Maslow group in Berlin. His relations with this essentially intellectual grouping may perhaps be compared with the pro-Bolshevik 'Nucleus' within the CPGB, in which Pollitt similarly provided a proletarian figurehead for a younger group of intellectuals working from the Labour Research Department. Already as a result of their October 1922 organization report, Pollitt and his closest collaborator R. Palme Dutt had secured minority representation on the party executive. The Fischer-Maslow group, including Thälmann, obtained a similar representation the following May on the basis of a compromise forged in Moscow to prevent the KPD fragmenting along factional lines during the crisis year of $1923 .^{44}$

In Germany, the grouping's subsequent rise and fall was to leave Thälmann alone in place as the plausible agent of bolshevization as a form of proletarianization. In Britain, on the other hand, the CPGB already had a working-class leadership that showed little interest in competing political platforms or Comintern controversies. In due course, the Comintern functionary Manuilsky was to deride its easy-going ways as those of a society of great friends. ${ }^{45}$ For the time being, however, as the Comintern sought to eradicate destabilising influences, the CPGB's unflappable loyalism was a quality more highly valued. Instead, it was the earnest young conspirators around Pollitt and Dutt who threatened factional division on continental lines - though even they operated semi-clandestinely. Resistance to any wholesale renewal of the party leadership meant that Pollitt therefore had to bide his time until the Comintern itself decided to engineer such a change as a means of enforcing Class Against 
Class. By the time that his leadership was properly established, any possible factional basis or rationale for it had long since disappeared.

The contrast with the intensely factional character of Thälmann's leadership meant that the role of a personalized leadership cult was also rather different. One of the classic functions of charismatic leadership is to provide an integration figure, whether in societies or in parties which are deeply fractured or unsettled. Another is to provide a sort of mobilization figure, whether to rally support to a regime or system of government, or as a personalized focus for competitive party politics. Any communist leadership cult combined elements of both of these. Nevertheless, Thälmann more than Pollitt was an integration figure, promising at once the transcendence and domination of faction. Pollitt, conversely, was more the mobilization figure, whose major contribution to British communism was not so much cohesion as political credibility. Even critics conceded Thälmann's rapport with communist supporters, and with his unmistakeable proletarian charisma Annette Leo concludes that workers saw him as one of their own. ${ }^{46}$ Already in the 1925 presidential election, his candidacy provided the focus for communist propaganda, as Die Rote Fahne depicted him with hammer in hand, a proletarian giant leading the 'red front' against its ill-assorted adversaries. ${ }^{47}$ In this sense too, Thälmann can be regarded as a proletarian 'integration figure', loyal to the party, steadfast in the struggle and combative towards the party's enemies. ${ }^{48}$ Nevertheless, where Pollitt's standing in labour movement circles was higher than his party’s, Thälmann's presidential polls in 1925 and 1932 compared unfavourably with Reichstag election results, and for non-communist workers he was a divisive figure and symbol of the doggedly pro-Moscow 'party communists' ${ }^{49}$ In due course, competition with the Nazis was to reinforce the tendency to depict him as a rival communist Führer. Nevertheless, the initial significance of Thälmann's leadership was as the instrument of factional dictatorship within the party.

Integration in this sense relied both on 'iron proletarian discipline', as a form of integration by exclusion, and on the projection of unified leadership as a focus for this discipline. Recent research confirms that purges, as enjoined by the Comintern, had been a feature of German party life from the outset. ${ }^{50}$ What distinguished the Stalinization process over which Thälmann presided was their systematic character. ${ }^{51}$ In two main waves of purges between 1925 and 1929, twelve groupings or factions were expelled from the party, with devastating implications for its activist base. ${ }^{52}$ Thälmann himself invoked Stalin's example in 
the battle against opportunists and conciliators, and after the second wave of purges continued to expound on the need to purge the party of the 'enemy within'. ${ }^{3}$ This was the model which Manuilsky two months later commended to the CPGB: 'The German comrades carefully weigh every word spoken by anybody. They allow no deviation from the line, they attack the least deviation, respecting no persons. ${ }^{54}$ In Britain, however, the main disciplinary headache was not factionalist 'deviation' but maintaining political direction of communists working in broader movements. In any case, an exiguous membership left little scope for purges on the German model. Annie Kriegel once observed that a scarcity of activists could necessitate treating those that did exist with 'kid gloves'; and of all parties the early CPGB had perhaps the greatest such scarcity relative to expectations. ${ }^{55}$ Whatever the explanation, purges were not even mentioned in the seminal Pollitt-Dutt Report on Organisation of 1922. Moreover, bolshevization itself was interpreted in the sense of a mass party avoiding unnecessarily onerous conditions of membership and the over-zealous removal of defaulting members. ${ }^{56}$

For Thälmann. factional dictatorship and the symbolic representation of strong leadership went hand in hand. Already in the mid-1920s many features of the subsequent Führerkult were beginning to be attributed to him. With the failure to remove him in 1928, his position became unassailable - at least from below. An account of the twelfth party congress in 1929 describes him entering the hushed congress hall 'in the Stalin manner'; flanked and followed by a retinue of subordinates, he seemed a 'king among his subjects'. ${ }^{57}$ According to the official congress protocol, his appearance on the platform was greeted with a 'tumultuous ovation' as delegates rose to sing the Internationale and the youth section called out 'Heil Moscow' ${ }^{58}$ Anything lacking in charisma was made up for by a sense of theatre. When Thälmann addressed a rally, proceedings would be opened by drum rolls and slogans shouted into megaphones, followed by marching columns of workers, the unemployed and party auxiliary groups. Thälmann himself would then be carried in by the 'strong fists' of the Mass Self-Defence squadrons that had replaced the RFB after its banning in 1929. 'Again and again', ran the report of a 1932 rally, 'there was burning applause, the enthused shouts, the greetings for Ernst Thälmann as an expression not only of enthusiasm, but of the proletarian love of the masses for their revolutionary Führer'. Ripping off his tie, Thälmann would speak, even shout, in his native Hamburg dialect, in a staged routine aiming at a direct emotional connection with the audience. At once a leader in his own right and the personification of 
collective communist virtues, his air of proletarian authenticity was unmatched by any possible rival. ${ }^{59}$ Even within the party hierarchy the myth began to be confused with reality. ${ }^{60}$

If Thälmann too internalized the myth, there is no sign that it engendered a greater sense of his own authority in relation to Moscow. His possession only of a severely compromized biography may explain why this early leadership cult in Europe's most prestigious communist party was held to pose no serious threat to Moscow's central control. The impact of the Wittorf affair, when even zealous stalinists expressed doubts about Thälmann, had been to publicly underline his dependency on Moscow's patronage. Even Thälmann's own party district had opposed his reinstatement. At the same time, the factional basis of his leadership remained a source of vulnerability. Unlike Stalin and his later epigones, Thälmann was not the KPD's general secretary: his position neither stemmed from, nor resulted, in control of the apparatus, but represented an adaptation of the public projections of leadership associated with the Lenin cult. Behind this façade, power struggles within the leadership persisted on the three-man secretariat on which Thälmann sat with Heinz Neumann and Hermann Remmele. At central committee discussions during 1932, Thälmann often found himself isolated, and Neumann even trespassed on his public preogatives in contriving a shift from personality to party in that year's presidential election campaign. ${ }^{61}$ Following disappointing results in Berlin and Hamburg, Thälmann was made to admit to the party's shortcomings in print: a sign again of the double-edged character of an instrument like selfcriticism, which could be used to undermine intermediate leadership figures. That Thälmann survived, while Neumann and Remmele were removed from the leadership, was possibly less a recognition of his indispensability than of his client status. A disjuncture thus remained between the public and private faces of leadership, and increasingly behind the scenes Moscow's authority upheld by the ILS-trained apparatchik, Walter Ulbricht. ${ }^{62}$ Though Ulbricht could never have rivalled Thälmann's popular appeal, he did underline its largely ceremonial character. No evidence has yet been traced of any significant dissension between Thälmann and Moscow, nor even of his seeking to exercise meaningful discretion in his own party's affairs.

\section{Biographical resources and personal capital}


Bolshevization, as previously noted, required the narrowing down of class to the 'iron proletarian discipline' by which class values became conflated with the party as political agent. ${ }^{63}$ Class, however, was freighted with other associations, often contradictory ones, and its use as a tool of authentication always contained the possibility of its own subversion. ${ }^{64}$ Even within the Bolshevik tradition - for example in the Workers' Opposition of 1919-21 - it provided a rhetoric and scale of judgement that could be set against the logic of party hierarchy or 'bureaucracy'. Beyond it, 'syndicalism' provided one possible foundation for such attitudes; and the communist bugbear of 'labour aristocracy' another, perhaps still more dangeous because embedded in the rival institutions of reformism. When Stalin in a German context extolled the 'struggle of the non-organised workers' against the constraints of the unions, this did not therefore represent a belated enthusiasm for spontaneity. ${ }^{65}$ What Stalin distrusted in the 'organized' worker - organized, that is, under non-communist auspices were accretions of loyalty, custom and association beyond the party's control. The ultrasectarianism of Class Against Class was the most extreme manifestation of this distrust. Nevertheless, the attempted construction of class in terms that excluded its core institutions, as Class Against Class did in the west, was inherently unstable. When Stalin within the USSR subsequently retreated from 'divisive proletarian values' to concepts of the nation, state or people, this did not by the mid-1930s imply any relaxation of party control; rather the opposite. On the other hand, the extension of a rhetoric of unity and legitimation to institutions not yet under communist control, as in the west, had rather different implications. Class Against Class was a little like War Communism in its fantasy of a tabula rasa on which a revolutionary party or society could be established. The popular front, like NEP, on the other hand, was like a concession to the intractability of older values and motive forces.

Biography was one of the main fields through which such tensions were alternatively managed or articulated. Like many historians, Sheila Fitzpatrick stresses the importance of the 'then' and 'now' in Soviet constructions of the self. However, if this could mean 'tearing off the mask' by the exposure of past liabilities, biography could also provide a source of moral or political capital that was not reducible to the 'mask' of model party member. In this respect, Pollitt's delayed advancement to the party leadership gave him extensive experience of negotiating these tensions even within a party context. As NMM secretary until 1929, he was centrally concerned with maintaining links and networks with the non-communist left. Until 
disqualified in 1928, he was also a Boilermakers' delegate to annual conferences of the Labour Party and Trades Union Congress. In the Comintern press he upheld the conventions of the 'English Movement' in 'conducting its politics in a 'gentlemanly" way'; on assisting in the Reichstag elections in December 1924 it was for its neglect of union issues and 'merciless' ridicule of social democrats that he criticized the KPD. ${ }^{66}$ Associations of this type could not but across the notion of the party as 'total institution', excluding other influences. ${ }^{67}$ In 1929 , the SPD's London correspondent Egon Wertheimer expressed astonishment at the warmth with which Labour delegates received communist speakers whose arguments they rejected. Pollitt in particular, according to the 'renegade' communist Ellen Wilkinson, received fulsome tribute 'to his personality and the genuine liking and respect which he was won from all sections of the Labour movement'. Wertheimer himself proved so susceptible to this 'noncommittal affection' as to describe him as 'tower[ing] head and shoulders above the average trade-union leader'. ${ }^{6}$

A naïve view is that such biographical details did not matter, as earlier instincts and associations were simply 'displaced' by Stalinist ones. Certainly, Pollitt was a confirmed party functionary, well-integrated into Comintern structures, by the time that he began to be projected as the CPGB's 'outstanding leader' in the mid-1930s. Ironically, it was therefore only after Thälmann's imprisonment that he began to assume a similar public profile to his. It was in 1934, for example, that Dutt urged Pollitt to assume the 'full Thaelmann position as the visible leader of the widest powerful mass opposition movement against Mosley, Fascism and War'. This, Dutt explained, demanded 'real living LEADERSHIP ... and in reality that means YOU'. ${ }^{69}$ Already in 1932, the CPGB's customary printed congress report had been replaced by Pollitt's address as secretary. By 1935, this carried the personalized title Harry Pollitt Speaks...

Pollitt did not, however, speak only with the Comintern's voice. Instead, his wellknown rejection of Moscow's anti-war line in September-October 1939 represented the culmination of a series of disillusionments over the previous two years. One was the arrest as spies in 1937 of his close friends Rose Cohen and Max Petrovsky, over whom Pollitt is said to have made strong private representations. ${ }^{70} \mathrm{He}$ also reacted strongly to Manuilsky's criticisms of the CPGB at the CPSU congress of March 1939, and two months later proposed vacating his position over the Comintern's imposition of a virtual volte-face over British conscription. 
What was striking in such exchanges was how Pollitt sought to throw into the balance his own personal leadership resources. As he pointedly reminded his central committee colleagues at the start of the war: 'I was in this movement practically before you were born, and will be ... a long time after some of you are forgotten. ${ }^{71}$

Possible factors contributing to such a stance can only be touched upon here. Class was one. Until 1927 Pollitt had continued intermittently to work at his trade to remain eligible for official union responsibilities, and this remained important as a psychological resource. When Thorez in 1939 made an even greater adjustment to the new Comintern line, his biographer notes by way of explanation that the only life now available to him was that of a Comintern functionary. ${ }^{72}$ This was not quite true of Pollitt, and the fact that he did briefly return to the shipyards was to provide a crucial part of the Pollitt myth. 'One thing I do know', his mother wrote to him on this occasion, 'I would not lose my dignity, by having an office boy's job, \& being dictated to, by someone not half so competent, because the tools are still in vaseline.' Prominently advertized in his autobiography, these sentiments provided both psychological resource and a source of political judgement counteracting the political contortions of Comintern loyalists. 'I was 23, had never heard of Bolshevism', Pollitt recalled of the outbreak of the First World World War in the central committee debates regarding the second one:

Had never heard of the Basle resolution, but had a class instinct which was sound and ... got as many physical beatings up for ... endeavouring to get that war transferred into a civil war as any person in this country. Has got the same class instinct ... now, and say that whether it is the Second Imperialist war or the Third one, if ... there is a chance for the smashing of fascism ... that alone is justification for the line we are putting forward. $^{73}$

Given these outspoken sentiments, explicitly directed against the 'disappearance of internationalism' from Moscow's own pronouncements, it is interesting that this did not mean the end of Pollitt's leadership career. As late as 1934, he had complained of pressures to have him removed from the leadership, and seems to have been especially distrustful of returning Lenin School students. ${ }^{74}$ Nevertheless, there was no real factional basis to such divisions, and 
the instability of Moscow's own positions meant that Comintern loyalism alone could hardly provide one. By 1937, soundings regarding Pollitt's replacement at the time of Cohen's and Petrovsky's arrests are said to have met with the resistance of his colleagues. There was no nobody who could take on his public functions; and during his demotion from 1939 to 1941 nobody did.

Two other considerations may be linked with this. The first was that Pollitt's functions of mobilization and legitimation, more perhaps than those of integration, were consistent with their performance by a variety of leadership figures. ${ }^{75}$ Already before 1939 , the election of William Gallacher as sole communist MP provided an obvious such figure, who quickly provided one of the earliest of the Comintern's exemplary autobiographies. Other such figures, also depicted biographically, included the veteran Tom Mann and the unemployed workers' leader Wal Hannington. Pollitt's role of mobilization figure meant that he enjoyed significant authority beyond the party which the CPGB in 1939 could ill afford to alienate. At the same time, the more collective performance of such functions meant that he could continue to make a significant, perhaps unequalled, contribution in this regard, even while deprived of the general secretaryship. Hence, of course, the paradox that Pollitt wrote and published his own exemplary party life at the very moment of his demotion.

A final factor would bear more systematic examination. This is the extent to which Pollitt's role as general secretary eventually provided him with a leverage over appointments and communications which Thälmann as chairman had lacked. Already as secretary of the Minority Movement, he had been accused of running a 'one-man show' in which he decided appointments and destroyed official correspondence without circulating it. ${ }^{76}$ His suppression ten years later of a Comintern telegram regarding the character of the war was to play a significant part in the discussions that then ensued, and it is clear that Pollitt had become acclimatized to the more relaxed day-to-day oversight of the CPGB's affairs. With no Comintern representative permanently stationed in Britain, nor even by 1938 attending the national party congress, Pollitt also began to exercise appreciable powers of patronage. Beneficiaries included the central committee appointee William Cowe, who had returned in virtual disgrace from the Lenin School for his strong 'traces of labour aristocracy'; the Fleet Street journalist William Forrest, whom Pollitt offered the editorship of the Daily Worker; and the future party secretary John Gollan, whom Pollitt by the late 1930s was already grooming 
as secretary of the Young Communist League. With the additional role that he played in the generation of party finance, Pollitt's functions were evidently not quite the same as those assumed by Thälmann in the course of stalinization. ${ }^{77}$

For rather complex reasons, Pollitt's independent resources as party leader were in some respects significantly greater than Thälmann's, and the day-today constraints upon him somewhat weaker. In one sense, this merely confirms the validity of the stalinization thesis for the party and period for which it was developed. At a somewhat platitudinous level, it also confirms that, even despite such variations, no communist leader remained a communist leader except by accepting the ultimate authority of the Comintern. At the same time, personal political capital, in this case anchored in class identities; the weakness or otherwise of factional rivalries; and the degree of control over patronage and communications, all meant that significant variations were nevertheless possible within this broader framework. Ironically, it was precisely because Pollitt's relationship with his party was in many respects closer to Stalin's than was Thälmann's that he had greater scope to establish a less dependent style of leadership. Internationally, more perhaps than in Russia itself, the creation of little Stalins was not just the uncomplicated exercise in discipline through emulation that it at first appears.

\footnotetext{
${ }^{1}$ For a summary of the 'Stalinization-thesis' with specific reference to Thälmann, see Hermann Weber, Der Thälmann Skandal. Geheime Korrespondenzen mit Stalin (Berlin: Aufbau-Verlag, 2003), pp. 12-17

${ }^{2}$ As for example in Marcel Liebman, Leninism Under Lenin (London: Merlin, 1980 edn), pp. 433-7. For the Stalinist cults see for example Franz Borkenau, World Communism, European Communism (London, 1953), p. 394; Maurice Duverger, Political Parties. Their organization and activity in the modern state (London: Methuen, 1954 edn), pp. 177-84.

${ }^{3}$ Marc Lazar, Le communisme: une passion française (Paris: Perrin, 2005 edn), p. 117.

${ }^{4}$ On these questions, see Kevin Morgan, Gidon Cohen and Andrew Flinn, Communists and British Society 1920-1991 (London: Rivers Oram, 2007), ch. 4.

${ }^{5}$ See e.g. Ronald Grigor Suny, 'Stalin and his Stalinism: power and authority in the Soviet Union, 1930-53' in Ian Kershaw and Moshe Lewin, eds, Stalinism and Nazism. Dictatorships in comparison (Cambridge: Cambridge University Press, 1997), pp. 26-7; David Priestland, Stalinism and the Politics of Mobilization. Ideas, power and terror in inter-war Russia (Oxford: Oxford University Press, 2007), pp. 51, 291.
} 
${ }^{6}$ E.A. Rees, 'Leader cults: varieties, preconditions and functions' in Balázs Apor et al, eds, The Leader Cult in Communist Dictatorships. Stalin and the Eastern bloc (Basingstoke: Palgrave Macmillan, 2004), pp. 18-19.

${ }^{7}$ Sarah Davies, 'Stalin and the making of the leader cult in the 1930s' in Apor et al, Leader Cult, pp. 29-46.

${ }^{8}$ Rosa Levine Meyer, Inside German Communism, p. 154.

${ }^{9}$ See the comments of his political ally R. Palme Dutt, 'Rough draft on some experiences of the Communist International and the period of Stalin's leading role', 1970, CPGB archives.

${ }^{10}$ For a summary of the Wittorf affair, see Norman LaPorte, The German Communist Party in Saxony, 1924-1933 (Bern: Peter Lang, 2003), pp. 239-45.

${ }^{11}$ See for example Claude Pennetier and Bernard Pudal. 'Stalinisme, culte ouvrier et culte des dirigeants' in Michel Dreyfus et al, Le siècle des communismes, Paris: Les Éditions de l'Atelier, 2000, pp. 369-76; Michelle Perrot, 'Les vies ouvrières' in Pierre Nora, ed., Les Lieux de mémoire (Paris: Gallimard, 1997 edn), pp. 3937 ff.

${ }^{12}$ See e.g. David Brandenberger, 'Stalin as symbol: a case study of the personality cult and its construction' in Sarah Davies and James Harris, eds, Stalin: a new history (Cambridge:

Cambridge University Press, 2005), pp. 249-70.

${ }^{13}$ See e.g. Kevin Morgan, Labour Legends and Moscow Gold. Bolshevism and the British Left part 1 (London: Lawrence \& Wishart, 2006), pp. 228-9.

${ }^{14}$ Reproduced Kevin McDermott and Jeremy Agnew, The Comintern. A history of international communism from Lenin to Stalin (Basingstoke: Macmillan, 1996), pp. 226-8

${ }^{15}$ See the chapter in this book by Jean-François Fayet,

${ }^{16}$ See 'Protokol der Sitzung der Polsekretäre und Redakteure', 1 September 1925 in SAPMO I 2/2/6, B1. 5ff.

${ }^{17}$ Weber, 'Einleitung' in Weber, Thälmann-Skandal, pp. 16-17.

${ }^{18}$ Stalin, 'The prospects of the Communist Party of Germany and the question of Bolshevisation' (February 1925) in Stalin, Works. Volume 7: 1925 (Moscow, Foreign Languages Publishing House, 1954), p. 37.

${ }^{19}$ Stalin, 'Foundations of Leninism' (April 1924) in Leninism, trans. Eden and Cedar Paul (London: Allen \& Unwin edn, 1928), p. 173.

${ }^{20}$ For which see e.g. Sheila Fitzpatrick, Tear Off the Masks! Identity and imposture in twentieth-century Russia (Princeton \& Oxford: Princeton University Press, 2005), chs 2-4 ${ }^{21}$ See for example the British student reports dated 27 May 1935 in RGASPI 495/100/993. ${ }^{22}$ For a valuable summary of many aspects of the image of Thälmann promoted by the KPD leadership, see Peter Maslowski, Thälmann (R. Kittner Verlag: Leipzig, 1931). On the East German construct of Thälmann's youth and Thälmann's own autobiographical writings, see Regina Scheer, 'Legende und Wirklichkeit' in German Monitor, pp. 41-56.

${ }^{23}$ See e.g. Claude Pennetier and Bernard Pudal, 'Les autobiographies des "fils du peuple". De l'autobiographie édifiante à l'autobiographie auto-analytique' in Claude Pennetier and Bernard Pudal, eds, Autobiographies, autocritiques, aveux dans le monde communiste (Paris: Belin, 2002), p. 227.

${ }^{24}$ Ernst Thälmann, 'Gekürtzte Lebenslauf' (n.d.) in: Nachlaß Ernst Thälmann, SAPMO NL 4003/1 (pp. 29), B1. 5, 7.

25 Thälmann, 'Gekürtzter Lebenslauf', B1. 9-10. 
${ }^{26}$ Claude Pennetier and Bernard Pudal, 'Du parti bolchevik au parti stalinien' in Dreyfus et al, Le siècle des communismes, pp. 338-9.

${ }^{27}$ See for example Balázs Apor, 'Leader in the making: the role of biographies in constructing the cult of Mátyás Rákosi’ in Apor, Leader Cult, pp. 63-80.

${ }^{28}$ In Thorez's case, his grandfather; see Edward P. Johanningsmeier, The Forging of American Communism. The life of William Z. Foster (Princeton, N.J.: Princeton University Press, 1994), p. 25; Maurice Thorez, Fils du peuple (Paris: Editions sociales, 1950 edn), ch. 1.

${ }^{29}$ The classic study remains, E. Fromm, The Working Class in Weimar Germany. A Psychological and Sociological Study (Leamington Spa: Berg Publishers, 1984). On the construction of masculinity in the KPD more generally, see Weitz, Creating German Communism, pp. 189-205.

${ }^{30}$ We develop this point in 'Red Front Fighter and Trade Union Militant: Ernst Thälmann, Harry Pollitt and the construction of the healthy proletarian leader in the 1920s', Jahrbuch für Historische Kommunismusfirschung (2008).

${ }^{31}$ Harry Pollitt, Serving My Time (London; Lawrence \& Wishart, 1941 edn), p. 50.

${ }^{32}$ Ref for friend-foe dichotomy.

${ }^{33}$ For a fuller discussion see Kevin Morgan, 'Harry Pollitt, Maurice Thorez and the writing of exemplary communist lives' in Julie Gottlieb and Richard Toye, eds, Making Reputations: power, persuasion and the individual in British politics (London: I.B. Tauris, 2005), pp. 5669.

${ }^{34}$ For Thorez's identity as a coalminer, see Stéphane Sirot, Maurice Thorez (Paris: Presses de Sciences Po, 2000), ch. 6.

${ }^{35}$ Scheer, 'Legende und Wirklichkeit', p. 49 [cites Nachlaß]; Weber, 'Thälmann-Bild', in GM, (pp. 7-15) p. 8.

36 Thälmann, 'Gekürtzter Lebenslauf', B1. 18-22, 23-24, 26-27.

${ }^{37}$ R. Fischer, Stalin and German Communism, p. 146.

${ }^{38}$ Interview with Noreen Branson, Imperial War Museum, London.

${ }^{39}$ RGASPI 495/100/68, 'Statement of the impressions of Comrade Hardy regarding the situation within the CPGB', 25 November 1930.

${ }^{40}$ Ibid, B1. 27-28.

${ }^{41}$ See Lucas

${ }^{42}$ Pollitt, Serving My Time, p. 126.

${ }^{43}$ On this, see Brandenberger, 'Stalin as symbol'.

${ }^{44}$ See respectively, see Kevin Morgan, Harry Pollitt (Manchester: Manchester University Press, 1993), ch. 2.

${ }^{45}$ Inprecorr (English edn), 25 September 1929, p. 1140.

${ }^{46}$ Leo, 'Heldenbild', pp.19-20.

47 'Wählt rot: Thälmann', Rote Fahne, 26 April1925,

${ }^{48}$ For this characterization, see Reuter, pp. 92-6.

${ }^{49}$ See for example, K. Rosenfeld, 'Berliner Blutmai' in Klassenkampf, 15 May 1929.

${ }^{50}$ Wirsching/Mallmann etc....

${ }^{51}$ For a case study of developments in saxony, see LaPorte, 'Saxon KPD', pp. 133-73.

${ }^{52}$ Esp. Bahne, 'Zwischen "Luxemburgismus" und "Stalinismus"....

53 See SAPMO, RY1, 11/26. B1.506-10, KPD twelfth congress, closed session; also Weber, Thälmann-Skandal, p. 19. 
${ }^{54}$ Inprecorr (English edn), 25 September 1929, p. 1140.

${ }_{56}^{55}$ Kriegel, French Communists, 235.

${ }^{56}$ See Morgan et al, Communists and British Society, ch. 2.

${ }^{57}$ Rosa Levine Meyer, Inside German Communism, p. 154

${ }^{58}$ Cited Flechtheim, Die KPD, p.203.

${ }^{59}$ For reports of Thälmann rallies see Die Rote Fahne, 27 February and 13 September 1932; for later accounts see Leo, 'Heldenbild, pp.20f; Buber-Neumann, Von Potsdam, p.110.

${ }^{60}$ Levine-Meyer, Inside German Communism, p. 126.

${ }^{61}$ See SAPMO RY 1/I 2/59, B1. 56-9.

${ }^{62}$ See Podewin, Walter Ulbricht, pp. 71-77.

${ }^{63}$ Used already in the original Comintern theses on Bolshevization, 'iron proletarian discipline' became a Bolshevizer's catchphrase.

${ }^{64}$ This is a major theme in Priestland, Stalinism and the Politics of Mobilization.

${ }^{65}$ Stalin, 'The right danger in the German Communist Party' (December 1928) in idem, Works. Volume 11: 1928-March 1929 ( Moscow: Foreign Languages Publishing House, 1954), pp. 313-14.

${ }^{66}$ Pollitt, 'The Liverpool Labour Party conference', Inprecorr (English edn), 15 October 1925, pp. 1099-1100; RGASPI 495/100/180, Pollitt, 'Report on German election', December 1924.

${ }^{67}$ For a recent example, without any modifying descriptor, Lazar, Le Communisme, p. 132.

${ }^{68}$ Egon Wertheimer, A Portrait of the Labour Party (London: Putnams, 1929), pp. 29-30, 37 8; also Wilkinson in Lansbury's Labour Weekly, 16 October 1926.

${ }^{69}$ Dutt papers, British Library, Cup 1262 K4, Dutt to Pollitt, 20 July 1934; see also Free Our Fighters! (London: Labour Defence Publications, 1934).

${ }^{70}$ See the entry on Cohen by Kevin Morgan and Gidon Cohen in Keith Gildart, David Howell and Neveille Kirk et al, (eds), Dictionary of Labour Biography vol. 11 (Basingstoke: Palgrave Macmillan, 2003).

${ }^{71}$ CPGB archives, CPGB central committee 2 October 1939.

${ }_{72}^{72}$ Philippe Robrieux, Maurice Thorez: vie secrète et vie publique, Paris, 1975, pp. 247-8.

${ }^{73}$ CPGB archives, Pollitt, central committee report, 24 September 1939.

${ }^{74}$ CPGB archives, CPGB central committee minutes, 6 April 1934.

${ }^{75}$ See Kevin Morgan, 'Ainsi pour Gallacher? Quelques regards sur la construction de la vie communiste modèle en Grande Bretagne', Communisme, 87, 2006, pp. 29-46.

${ }^{76}$ RGASPI 495/100/514, Hardy to CPGB political bureau, 5 October 1928.

${ }^{77}$ On finance, see Morgan, Labour Legends, ch. 7. 